\title{
履歴減衰装置の極低サイクル疲労特性と実地震応答下における 疲労寿命の予測 \\ ON LOW-CYCLE FATIGUE CHARACTERISTICS OF HYSTERETIC DAMPER AND ITS FATIGUE LIFE PREDICTION UNDER SEVER EARTHQUAKE GROUND MOTION
}

\author{
玉井宏章*，近藤一夫**，花井正実*** \\ Hiroyuki TAMAI, Kazuo KONDOH and Masami HANAI
}

\begin{abstract}
A new effective hysteretic damping device for improving the seismic resistance characteristics of a Xbraced frame structure, in which the seismic energy is absorbed into the plastic deformation of the perforated steel plate in the device, was proposed in the authors previous papers.

In this paper, the low-cycle fatigue characteristics of the present damping device are investigated. The applicability of the fatigue relation and the linear accumulation damage rule to the device is confirmed through constant amplitude and high-to-low block loading tests. Also, the life prediction expression of the present device is shown and its availability is verified by non-stationary amplitude fatigue tests using the deformation time history of the hysteretic damper in the on-line computer-actuator control test.

It is clarified that the accumulation damage value of the damping device is small in the responses of the building with proper dynamic structural characteristics under a severe earthquake ground motion ( with about 60 kine in the maximum ground velocity ), and thus the present device has enough energy absorption capacity.
\end{abstract}

Keyword : very low cycle fatigue, hysteretic damper, fatigue life prediction

極低サイクル疲労・履歴隇衰装置・疲労寿命予測

\section{1. 序}

文献 1)、2) では、著者らが提案するブレース制振装置 付架構について、オンライン・コンピュータ制御実地震応 答実験を行い、その応答性状および履歴減衰装置の履歴特 性、エネルギー吸収性能等を調べ、烈震時にも、はり、柱 は弾性範囲内に留まり、かつ、履歴減衰装置の復元力特性 に少化も生じないこと等を明らかにした。

この構造形式では、烈震程度の地震に対しては、損傷を 受けるのは履歴減衰装置のみであり、地震後に履歴減衰装 置を取り替えることにより、建物を元の健全な状態に容易 に修復することが可能であるが、地震後に履歴娍衰装置の 取り替えを行うか否かは、現時点での装置の損傷度がどの 程度であるかを把握し、次の予想される地震に対しても破 壊や復元力特性の劣下を起こすことなく、その性能が良好 に発揮されるかどうかを十分検討して判断する必要がある。 こうした観点から、本報告では、定振幅、2段 2 重等の 各種の疲労試験を行い、本履歴減衰装置の疲労寿命予測式 を提示すると共に、実地震に対する本予測式の有効性を検 討する。
また、実地震時の履歴減衰装置の累積損傷などを検討す るため、適正な構造特性を有する建物が $2 、 3$ 地震波を 受けた場合の実地震応答解析を行い、地震後の取り替え、 補修の判定基準についての資料を提示する。

$$
\text { ところで、鋼構造物の地震時における損傷度を評価する }
$$
代表的尺度として、現在、
i）望性率
ii）累積塑性変形応答倍率

iii）総履歴吸収エネルギーiv）低サイクル疲労累積損傷値 の 4 つがあり、i）、ii）、iii）の諸量は、建物の地震による 損傷度を計量する際によく用いられるが、構造物の破壊現 象が、どの程度で起こるか等の情報が十分には得られず、 また、一般の金属材料や鋼構造物の極低サイクル疲学実験 結果を良好に表現できない等の欠点もある ${ }^{5) 。 ~}$

本研究では、こうした点を考慮し、履歴減衰装置の損偒 評価の方法として、破壊現象に基礎をおくiv）の低サイク ル疲労累積損傷值 (以後、簡単に累積損傷值と呼ぶ) を用 いることにする。また、有孔鋼板全体にわたってのひず み分布を追跡することは、非常に困難であること、必要と する疲労特性、累積損傷等は、有孔鋼板全体についてのも のであることを考慮し、損傷評価の引数として、塑性ピン

\footnotetext{
*広島大学工学部建設構造工学 助手. 博士 (工 Research Assoc., Dept. of Structural Eng., Faculty of Eng., 学)

**広島大学工学部建設構造工学 助教授. 工博

****近畿大学工学部建築学科 工博

Hiroshima Univ. Dr. Eng

Assoc. Prof., Dept. of Structural Eng., Faculty of Eng., Hiroshima Univ. Dr. Eng.

Prof., Dept. of Architecture, Faculty of Eng., Kinki Univ. Dr. Eng.
} 
Table 1 Mechanical properties of materials

\begin{tabular}{|c|c|c|c|c|c|c|}
\hline & Young's & Hardening & $\begin{array}{c}\text { Nominal } \\
\text { Yield } \\
\text { Stress }\end{array}$ & $\begin{array}{c}\text { Nominal } \\
\text { Ultimate } \\
\text { Strength }\end{array}$ & $\begin{array}{c}\text { Strain at } \\
\text { Initial } \\
\text { Hardening }\end{array}$ & Elongation \\
\cline { 2 - 7 } & $t / \mathrm{cm}$ & $t / \mathrm{cm}^{2}$ & $t / \mathrm{cm}^{2}$ & $t / \mathrm{cm}^{2}$ & $\%$ & $\%$ \\
\hline SS41 & 2107.59 & 32.23 & 2.97 & 4.36 & 0.965 & 24.12 \\
\hline HT55 & 2124.20 & 32.98 & 5.09 & 6.37 & 0.948 & 29.35 \\
\hline HT60 & 2103.28 & 26.40 & 5.32 & 6.42 & 1.385 & 31.51 \\
\hline
\end{tabular}

間相対変位を採用する。

次節以降では、本研究で採用した実験方法及び実験装置の 概要に引き続き、まず、i）定振幅疲労実験を行い、MansonCoffin の疲労関係式の本履歴减衰装置への適用性を検証す る。次に、ii） 2 段 2 重疲労実験を行い、Palmgren-Miner の線形累積損傷則の適用性を示し、この損傷則を用いた疲 労寿命予測式を提示する。また、iii）文献 1）、2）の実地震 応答実験で得られたピン間相対変位時刻歴を用いた非定常 振幅度労夷験を行い、地震応答下における線形累積損傷則 の適用性を調べるとともに本疲労寿命予測式の予測精度を 検証する。更に、iv）実地震応答解析を行い、激・烈震時 における累積損傷值等を明らかにするとともに、損慯度の 尺度として通常よく用いられる塑性率、累積塑性変形応答 倍率と累積損傷值との間の相関関係を示す。

\section{2. 実験方法と実験装置の概要}

本研究で提案しているブレース制振装置付架構の概要を Fig.1に示す。ブレース制振装置は、鉄骨骨組の柱と梁の接 合部の四隅にブレースを接合し、その対角線上の中央部に 履歴減衰装置を設置したものであり、その詳細については、 文献 3),4) を参照されたい。

試験体は、中央孔と 8 つの楕円孔を有する有孔鋼板と 8 枚の連結材およびそれらを接合するピンとからなる履歴減 衰装置であり、この形状の有孔鋼板は、大きな繰り返し地 震力に対しては、棈円孔付近の低耐力部分が塑性变形して エネルギーを吸収し、安定した紡錘型の履歴特性と大きな エネルギー吸収性能を有し4)、また、中央孔と 8 つの楠円 孔の大きさを変えることによって、任意に酎力を調節する ことが可能である。本研究では、履歷減衰装置に用いる有 孔鋼板として、この形式のものの中から、その特性が最も 良好と考えられる S1LM 形状（文献 4) 参照）のものを採 用しており、その形状、寸法を Fig.2および Fig.3に示す。

用いた鋼材は SS41、HT55（NKK 規格、SW36 相当）、 HT60（NKK 規格、SM58 相当）の3種であり、試験体と 同質、同厚 $(0.55 \mathrm{~cm})$ の 5 号試験片 4 体について行った引 張実験結果の平均値を Table 1に、また、化学成分分析結 果を Table 2に、それぞれ、示す。

加力装置の概要を、Fig.4に示す。加力は、履歴減衰装置 を、試験体の回転を防止するために凸型と凹型をしたガイ ドプレートで挟み、その上下にネジ式のジョイントを高張 カボルトで取り付けて行う。試験体の上下方向に压縮力、引

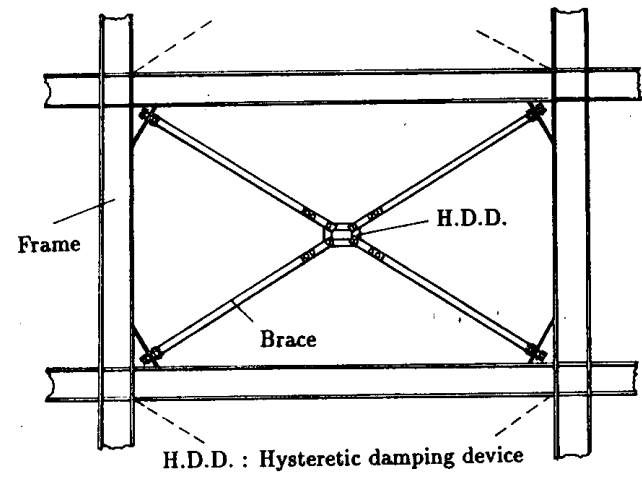

Fig. 1 Hysteretic damping device installed in X-braced frame

Table 2 Chemical composition of materials

\begin{tabular}{|c|c|c|c|c|c|c|c|c|c|c|c|c|}
\hline$\%$ & $C$ & $S_{i}$ & $M_{n}$ & $P$ & $S$ & $N_{i}$ & $C_{\mathrm{r}}$ & $N$ & $C_{\mathrm{V}}$ & $V$ & $N_{\mathrm{i}}$ & ofl.Al \\
\hline SS41 & 0.12 & 0.021 & 0.53 & 0.009 & 0.006 & 0.05 & 0.013 & 0.0053 & - & - & - & - \\
\hline HT55 & 0.14 & 0.360 & 1.35 & 0.017 & 0.003 & 0.02 & 0.020 & - & 0.01 & 0.01 & 0.03 & 0.044 \\
\hline HT60 & 0.12 & 0.440 & 1.53 & 0.010 & 0.002 & 0.02 & 0.020 & - & 0.02 & - & 0.03 & 0.031 \\
\hline
\end{tabular}

張力が作用すると、連結材の連結作用によって、有孔鋼板に は、上下、左右のピンから、交互に、圧縮力と引張力が作用 することになる。加力装置は、島津オートグラフ AG25TA を用い、荷重の計測は、クロスヘッド上部のロードセルで 行った。一方、変位の計測は、上下左右対角方向のピン間 相対変位を試験体の表裏計 4 本で行い、表裏の計測值を平 均した。また、Fig.3に示す楕円孔の端部 a,a',b, b',c,c'の 6 箇所に検長 $0.2(\mathrm{~cm})$ の箔ひずみゲージを貼付してひずみの 計測を行った。

加力方法は上下対角方向ピン間相対変位制御とした。な お、加力装置の詳細は文献 3) を参照されたい。加力プロ グラムとして、単調引張実験、正負交番漸増振幅実験、正 負交番定振幅疲労実験、正負交番 2 段 2 重疲労実験、非 定常振幅疲労実験を採用し、単調引張実験は、HT60 の試 験体についてのみ行う一方、3種すべての鋼種の試験体に ついて、ピン間相対変位振幅を $0.1(\mathrm{~cm})$ から $0.8(\mathrm{~cm})$ まで $0.1(\mathrm{~cm})$ 刻みで漸増させ各ループで 2 回載荷する漸増振幅 実験と、振幅を $0.21(\mathrm{~cm}) 、 0.30(\mathrm{~cm}) 、 0.44(\mathrm{~cm}) 、 0.66(\mathrm{~cm})$ とした定振幅疲労実験並びに振幅を $0.60(\mathrm{~cm})$ と $0.35(\mathrm{~cm})$ および $0.46(\mathrm{~cm})$ と $0.26(\mathrm{~cm})$ とする Step down 型の 2 段 2 重疲労実験を行った。また、HT60の試験体については、 文献 1)、2) で示した実地震応答実験の変位応答時刻歴を 数ブロック載荷した後に、 $0.40(\mathrm{~cm})$ の定振幅で載荷する非 定常振幅疲労実験を行い、履歴減衰装置の耐力が最大耐力 の 8 割に低下するまで繰り返し載荷した。

なお、本実験で採用したピン間相対変位振幅の值は、本 試験体寸法での最大振幅が $0.30 \sim 0.60(\mathrm{~cm})$ 程度となると いう地震応答解析結果などを参考に定めたものである。

\section{3. 履歴減衰装置の極低サイクル疲労関係式}

本節では、本履歴減衰装置の定振幅繰り返し載荷時にお ける極低サイクル疲労特性について考える。 


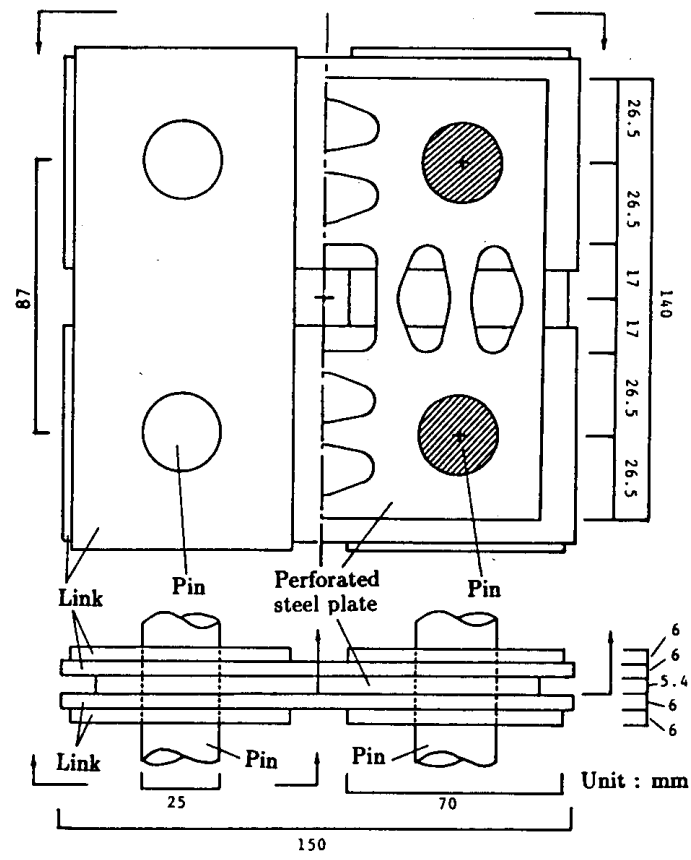

Fig. 2 A hysteretic damping device

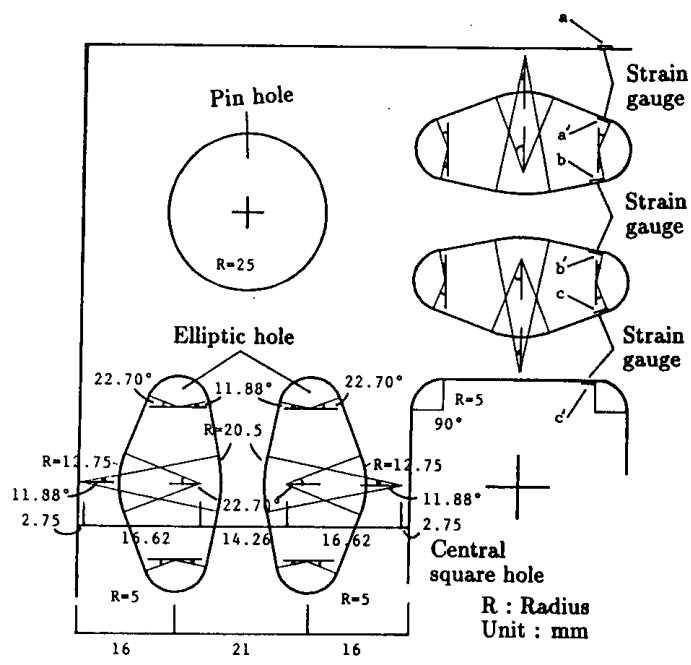

Fig. 3 Detail of a perforated steel plate

ところで、本研究では、疲労関保式の引数として、前述 のように塑性ピン間相対変位を採用する。そのため、本節 では、まず、単調引張試験により、ピン間相対変位と最も ひずみ集中が大きいと考えられる棈円孔端部のひずみとの 間の関係を調ベ、塑性ピン間相対変位と棈円孔端部の塑性 ひずみとの対応性を検討することにより、塑性ピン間相対 変位を引数として採用することの妥当性を梌証する。次い で、漸堌振幅実験より得られた骨格曲線を、Bi-linear 型 および Ramberg-Osgood 型の数値モデルに理想化するこ とにより、疲労関係式の引数として採用した塑性ピン間相 対変位振幅の算定式を誘導する。さらに、定振幅疲労実験 を行い、塑性ピン間相対変位振幅を用いた極低サイクル疲 労関係式を求める。

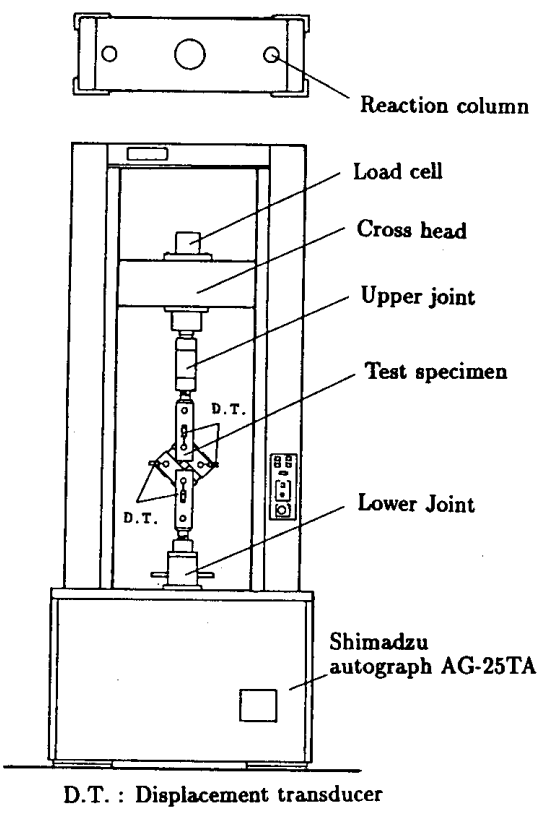

Fig. 4 Test setup

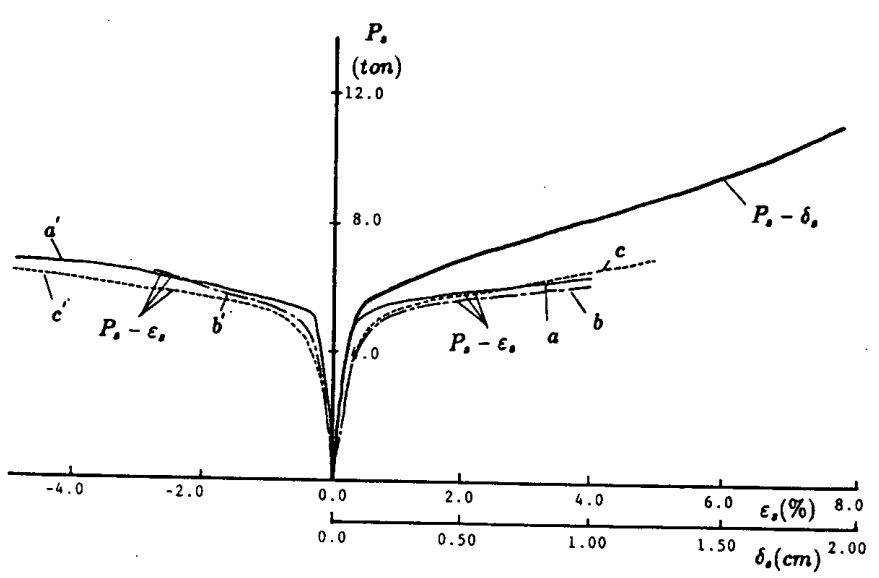

Fig. $5 P_{s}-\delta_{s}$ and $P_{s}-\varepsilon_{s}$ relations under monotonic loading

\section{1 塑性ピン間相対変位振幅算定式} ○ピン間相対変位と楕円孔端部のひずみとの間の関係

HT60 の有孔鋼板について行った単調引張実験より得ら れた荷重： $P_{s}$ とピン間相対変位： $\delta_{s}$ および棈円孔の端部 a,a',b,b',c,c'（Fig.3参照）に貼付したひずみゲージから得 られたひずみ值： $\varepsilon_{s}$ との関係を Fig.5に、また、ピン間相 対変位： $\delta_{s}$ と $\varepsilon_{s}$ との間の関係を Fig.6に示す。これ等の図 から、ピン間相対変位が $2.0(\mathrm{~cm})$ と大きくなっても、耐力 の低下は生じず、本履歴減衰装置は、高い 2 次勾配の十分 な塑性変形能力を有すること、また、 $\delta_{s}-\varepsilon_{s}$ 関係は、大略、 Bi-linear 型となっていることがわかる。また、 $P_{s}-\delta_{s}$ 関係、 $P_{s}-\varepsilon_{s}$ 関係とも、ほほ同程度の荷重值から第 2 分枝直線に 分岐していることから、ピン間相対変位の塑性変形成分： $\delta_{s}^{(p)}$ と塑性ひずみ: $\varepsilon_{s}^{(p)}$ との間にはほほ線形の対応関係があ り、従って、塑性ひずみ振幅： $\varepsilon_{s a}^{(p)}$ の代わりに塑性ピン間 相対変位振幅： $\delta_{s a}^{(p)}$ を極低サイクル疲労関係式の引数とし て用いても、実用上、差し支えないものと考えられる。 


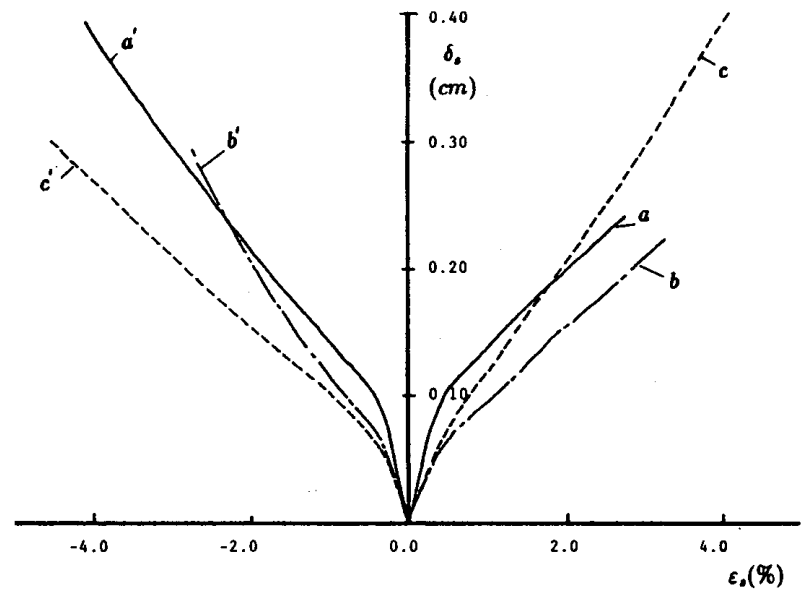

Fig. $6 \delta_{s}-\varepsilon_{s}$ relations under monotonic loading

\section{○塑性ピン間相対变位振幅の算定式}

次に、繰り返し載荷時の荷重振幅： $P_{s a}-$ ピン間相対変 位振幅： $\delta_{s a}$ 関係を求める。

本研究では、骨格曲線の数值モデルとして、文献 2) と 同様、Bi-linear 型および Ramberg-Osgood 型の $2 つ の モ$ デルを採用する。

文献 2) で行った、ピン間相対変位振幅を $0.10(\mathrm{~cm})$ から $0.80(\mathrm{~cm})$ まで $0.10(\mathrm{~cm})$ づつ漸増させ、各振幅で 2 サイク 儿繰り返す漸増振幅実験結果に、最小 2 乗近似法による直 線式をあてはめると、ピン孔周辺部が塑性化した以後の 2 サイクル目の荷重振幅值： $P_{s a}$-ピン間相対変位振幅值: $\delta_{s a}$ 関係は、3種の鋼材の有孔鎡板について、それぞれ、次式 のように表わされる。

$$
\begin{array}{ll}
P_{s a}=3.077 \cdot \delta_{s a}+3.181 & (\mathrm{SS} 41) \cdots \cdots \cdots \cdots(1-\mathrm{a}) \\
P_{s a}=4.800 \cdot \delta_{s a}+5.610 & (\mathrm{HT} 55) \cdots \cdots \cdots \cdot(1-\mathrm{b}) \\
P_{s a}=4.225 \cdot \delta_{s a}+5.690 & (\mathrm{HT} 60) \cdots \cdots \cdots \cdots(1-\mathrm{c})
\end{array}
$$

さて、Bi-linear 型モデルにおける塑性ピン間相対変位振 幅： $\delta_{\boldsymbol{s a}}^{(p)}$ は、次式で算定される注 1)。

$$
\begin{aligned}
& \delta_{s a} \leq \delta_{s y} \text { のとき } \\
& \delta_{s a}^{(p)}=0.0 \ldots \ldots \ldots \ldots \\
& \delta_{s a}>\delta_{s y} \text { のとき } \\
& \delta_{s a}^{(p)}=\delta_{s a}-\frac{P_{s a}}{P_{s y}} \cdot \delta_{s y}
\end{aligned}
$$

ここに、 $P_{s y}$ と $\delta_{s y}$ は、それぞれ、弾性限耐力および弾性 限ピン間相対変位であり、これらの值は、文献 3) に示し た有限要素解析により求めた弾性時の荷重一ピン間相対変 位関係と (1.a-c) 式との交点の值として定める。

一方、Ramberg-Osgood 型モデルでは、文献 6) に従い、 $P_{s a}-\delta_{s a}$ 関係を次式のように表す。

$$
\frac{\delta_{s a}}{\delta_{s y}}=\frac{P_{s a}}{P_{s y}} \cdot\left(1+b \cdot\left|\frac{P_{s a}}{P_{s y}}\right|^{a-1}\right)
$$

ここに、 $\delta_{s y}$ および $P_{s y}$ は、(2-b) 式で定めた弾性限ピン
Table 3 Mechanical properties of hysteretic damping device

\begin{tabular}{|c|c|c|c|}
\hline & SS41 & HT55 & HT60 \\
\hline \hline$a$ & 5.4345 & 6.7769 & 7.5048 \\
\hline$b$ & 1.1992 & 0.5964 & 0.6108 \\
\hline$\delta_{\text {ay }}(\mathrm{cm})$ & 0.04838 & 0.08762 & 0.08807 \\
\hline$P_{\text {ay }}(t)$ & 3.330 & 6.031 & 6.062 \\
\hline
\end{tabular}

間相対変位および弾性限荷重の値を採用し、また、式中の 定数 a、bは、漸増振幅実験より得られた荷重振幅一変位 振幅関係を、(3) 式により最小 2 乗近似することにより定 める。簡単化のため、除荷過程における有孔鋼板の挙動は 線形弾性的であるとすると、Ramberg-Osgood 型モデルに おける塑性ピン間相対変位振幅： $\delta_{s a}^{(p)}$ は、次式のように表 される。

$$
\begin{aligned}
\delta_{s a}^{(p)} & =\delta_{s a}-\frac{P_{s a}}{P_{s y}} \cdot \delta_{s y} \\
& =b \cdot \frac{P_{s a}}{P_{s y}} \cdot\left|\frac{P_{s a}}{P_{s y}}\right|^{a-1} \cdot \delta_{s y}
\end{aligned}
$$

実験に供した 3 種の鐥材について、求めた $\mathrm{a} ， \mathrm{~b}$ および $\delta_{s y}$ 、 $P_{s y}$ の值を Table 3に示す。

\section{2 定振幅疲労関係式}

次に、3 種の鍓材について、0.21 $(\mathrm{cm}) 、 0.30(\mathrm{~cm})$ 、 $0.44(\mathrm{~cm}) 、 0.66(\mathrm{~cm})$ の各振幅で、正負交番定振幅繰り返 し実験を行い、耐力が最大耐力の 9 割に低下するまでの 半ループ数： $N_{f}$ 注 2) を求めた結果を Fig.7、Fig.8および Table 4に示す。Fig.7は、各試験体についての引張時の荷 重振幅 $: P_{s a}$ と半ループ数: $N$ との関係を示したものであ り、また、Fig.8には、塑性ピン間相対変位振幅： $\delta_{s a}^{(p)}$ と $N_{f}$ との関係を、次式で与えられる、最小 2 乗近似法を用いて 得られた疲労予測実験式とともに示す。

$$
\begin{aligned}
& N_{f}=\frac{1}{2} \cdot\left|\frac{\delta_{s a}^{(p)}}{\delta_{s f}}\right|^{-1 / c} \\
& \text { ここに、 } \\
& \begin{array}{lll}
\delta_{s f}=9.2209, & c=0.62875 & (\mathrm{SS} 41) \cdots \cdots(6-\mathrm{a}) \\
\delta_{s f}=11.9515, & c=0.77476 & (\mathrm{HT} 55) \cdots \cdots(6-\mathrm{b}) \\
\delta_{s f}=11.8567, & c=0.76258 & (\mathrm{HT} 60) \cdots \cdots(6-\mathrm{c})
\end{array}
\end{aligned}
$$

であり、また、 $\delta_{s f}$ は、単調引張載荷時の破断相対変位で ある注 3)。なお、(6.a-c) 式の值は、塑性ピン間相対変位 振幅： $\delta_{s a}^{(p)}$ を、(2.a,b) 式により求めた場合の值であり、(4) 式を用いた場合には、 $\delta_{s f}$ および $c$ は、それぞれ、次の值と なる。

$$
\begin{aligned}
& \delta_{s f}=9.5109, \quad c=0.63591 \quad(\mathrm{SS} 41) \cdots \cdots(7-\mathrm{a}) \\
& \delta_{s f}=12.6253, \quad c=0.78789 \quad(\mathrm{HT} 55) \cdots \cdots(7-\mathrm{b}) \\
& \delta_{s f}=12.4707, \quad c=0.77435 \quad(\mathrm{HT} 60) \cdots \cdots(7-\mathrm{c})
\end{aligned}
$$



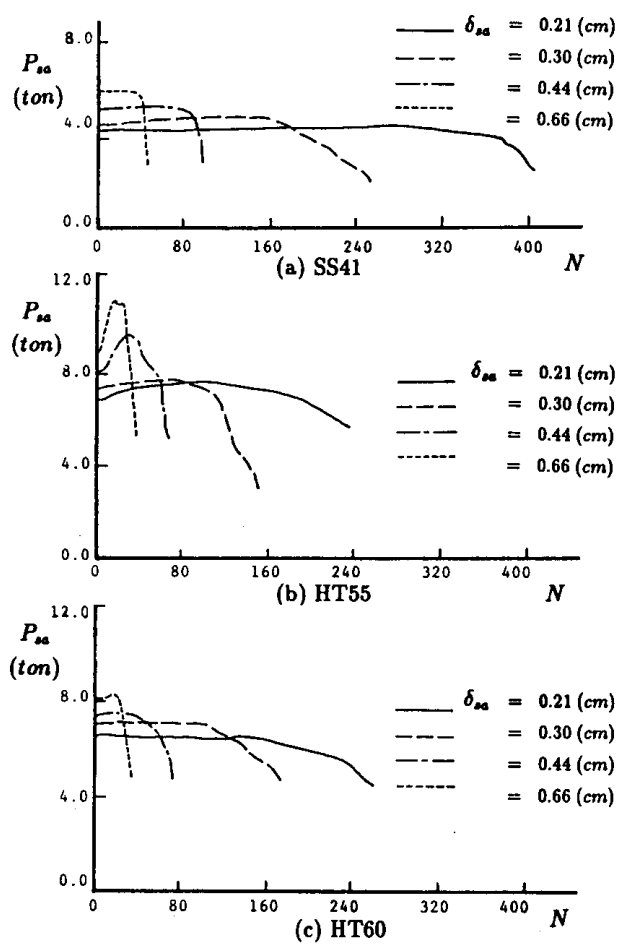

Fig. 7 Variations of strength with the number of half cycle under single level loading

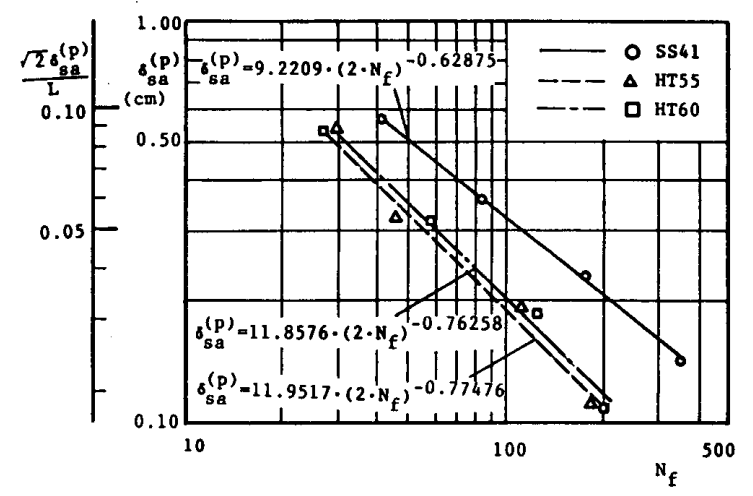

Fig. $8 \delta_{s a}^{(p)}-N_{f}$ relationship

$N_{f}$ とともに示している。 $\left(N_{f}-\delta_{s a}^{(p)}\right)$ 直線の相関俰数は、 0.99953 0.99036 と高い相関関係を示す值となっており、 いずれの鋼種についても Manson-Coffin 型の疲労関係式が よく成立することが分かる。なお、Fig.9には、ここで用 いた諸量への理解を容易にするため、 $P_{s a} 、 \delta_{s a} 、 \delta_{s a}^{(p)} お よ$ び $\delta_{s f}$ の定義を模式的に示している。

\section{4. 地覆応答下の疲労寿命予測}

前節では、定振幅載荷時における履歴減哀装置の疲労につ いて考え、Manson-Coffin 型の疲労関係式が良好に成立する ことを明かにした。本節では、この結果を基に、PalmgrenMiner の線形累積損傷則の本履歴減衰装置への適用性を調 べるとともに、これを用いた、地霞応答下における疲労寿 命予測式を示す。
Table 4 Low cycle fatigue characteristics under single level loading

\begin{tabular}{|c|c|c|c|c|c|c|c|c|c|c|c|c|}
\hline & \multicolumn{4}{|c|}{ S S 41} & \multicolumn{4}{|c|}{ H T 55} & \multicolumn{4}{|c|}{ H T 60} \\
\hline $\begin{array}{c}0_{00} \\
(\mathrm{~cm})\end{array}$ & 0.200 & 0.293 & 0.428 & 0.644 & 0.211 & 0.300 & 0.441 & 0.660 & 0.206 & 0.294 & 0.430 & 0.656 \\
\hline $\begin{array}{c}N_{f} \\
(\text { H.C. })\end{array}$ & 359.5 & 179.5 & 85.5 & 41.5 & 187.5 & 113.5 & 45.5 & 29.5 & 201.5 & 127.5 & 59.5 & 27.5 \\
\hline $\begin{array}{c}W_{p} \\
(t \cdot \mathrm{cm})\end{array}$ & 410.7 & 331.1 & 282.7 & 225.8 & 299.5 & 290.4 & 236.3 & 282.3 & 267.9 & 313.5 & 256.4 & 209.5 \\
\hline $\begin{array}{c}P_{\text {samas }} \\
(t)\end{array}$ & 4.50 & 4.82 & 5.34 & 6.00 & 7.55 & 7.59 & 9.55 & 10.97 & 6.56 & 7.13 & 7.49 & 8.21 \\
\hline \multicolumn{13}{|c|}{$\delta_{a b}^{(d)}$ calcolated by Eqs.(2),(6) } \\
\hline $\begin{array}{l}\delta(\underline{a}) \\
(\mathrm{cm})\end{array}$ & 0.145 & 0.234 & 0.363 & 0.569 & 0.115 & 0.198 & 0.329 & 0.532 & 0.111 & 0.193 & 0.321 & 0.533 \\
\hline & \multicolumn{4}{|c|}{$\delta_{f e}^{(5)}=9.2200 \cdot\left(2 N_{f}\right)^{-0.62875}$} & \multicolumn{4}{|c|}{$\delta_{96}^{G}=11.9515 \cdot\left(2 N_{f}\right)^{-0.77176}$} & \multicolumn{4}{|c|}{$\delta_{c \theta}^{(g)}=11.8567 \cdot\left(2 N_{f}\right)^{-0.76256}$} \\
\hline C.c. & \multicolumn{4}{|c|}{0.99953} & \multicolumn{4}{|c|}{0.99036} & \multicolumn{4}{|c|}{0.99104} \\
\hline \multicolumn{13}{|c|}{ Jculated by Eqs.(4),(7) } \\
\hline $\begin{array}{l}\delta_{a}^{(\text {(p) }} \\
(\mathrm{cm})\end{array}$ & 0.143 & 0.231 & 0.360 & 0.570 & 0.113 & 0.194 & 0.326 & 0.536 & 0.109 & 0.190 & 0.318 & 0.536 \\
\hline & \multicolumn{4}{|c|}{$\delta_{f 0}^{\left(C_{0}\right.}=9.5109 \cdot\left(2 N_{f}\right)^{-0.63591}$} & \multicolumn{4}{|c|}{$\delta_{f e}^{()}=12.6253 \cdot\left(2 N_{f}\right)^{-0.78760}$} & \multicolumn{4}{|c|}{$\delta_{g}^{(P)}=12.4707 \cdot\left(2 N_{f}\right)^{-0.774 .35}$} \\
\hline C.c. & \multicolumn{4}{|c|}{0.99953} & \multicolumn{4}{|c|}{0.99059} & \multicolumn{4}{|c|}{0.99167} \\
\hline
\end{tabular}
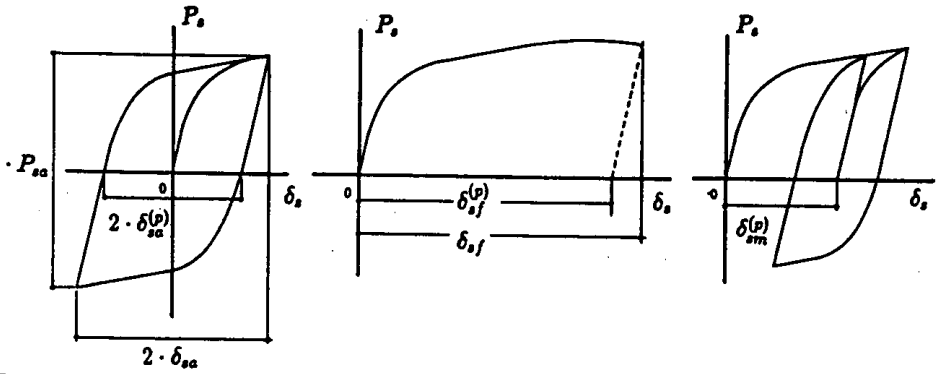

Fig. 9 Schematic sketches of $P_{s a}, \delta_{s a}, \delta_{s a}^{(p)}, \delta_{s f}$ and $\delta_{s m}^{(p)}$

\section{1 線形累積損傹則の 2 段 2 重載荷時への適用性}

まず、線形累積損傷則の本履歷減哀装置への適用性を検 証するために、非定常振幅疲労実験のうち最も単純な 2 段 2 重疲労実験を行った。載何形式は、ピン間相対変位振幅: $\delta_{s a}$ を $0.60(\mathrm{~cm}) \rightarrow 0.35(\mathrm{~cm})$ (Type A) および $0.46(\mathrm{~cm}) \rightarrow 0.26$ $(\mathrm{cm})$ (Type B) の Step down 型の正負交番 2 段 2 重疲労実 験とし、1 段目に (5) 式および (6-a) (6-c) 式から得られ る $N_{f}$ の半数回だけ繰り返した後、 2 段目の耐力が 2 段目 の最大耐力の 9 割に低下するまで繰り返し載荷し、その載 荷回数を求めた。

多段多重疲労実験における Palmgren-Miner 則による累 積損傷值は、次式のように表される ${ }^{7), 9) 。 ~}$

$$
D_{f}=\sum_{i}\left(\frac{N_{i}}{N_{f, i}}\right)
$$
ここに、

$N_{i} \quad: \mathrm{i}$ 段目の振幅時に加えた半ループ数

$N_{f, i} \quad:$ i 段目の振幅での定振幅実験で、 耐力が最大耐力の 9 割まで低下 した時の半ループ数

$(2 . \mathrm{a}, \mathrm{b})$ 式と (6) 式及び (4) 式と (7) 式により算定した $\delta_{s a}^{(p)}$ 用いて求めた $D_{f}$ の值を、履歴吸収エネルギー: $W_{p}$ ととも に Table 5に、また、その時の各ループの最大耐力 : $P_{s a}-$ 半ループ数: Nの関係を Fig.10に示す。Table 5より、Type A 、Type B とも、実験を行ったすへての鋼種について、 


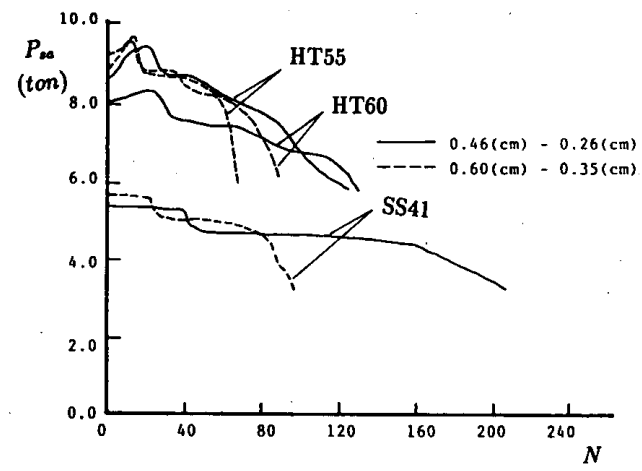

Fig. 10 Variations of strength with the number of half cycle under high-to-low block loading

Table 5 Damage factors under high-to-low block loading

\begin{tabular}{|c|c|c|c|c|c|c|c|c|c|}
\hline & \multirow[b]{2}{*}{$\begin{array}{c}\delta_{s a} \\
(\mathrm{~cm})\end{array}$} & \multirow[b]{2}{*}{$\begin{array}{c}N_{i} \\
\text { (H.C.) }\end{array}$} & \multirow[b]{2}{*}{$\underset{(t \cdot \mathrm{cm})}{W_{p}}$} & \multirow[b]{2}{*}{$\begin{array}{c}P_{\text {aamax }} \\
\text { (t) }\end{array}$} & \multicolumn{2}{|c|}{ from Eqs.(2),(6) } & \multicolumn{2}{|c|}{ from Eq8.(4),(7) } \\
\hline & & & & & & $\begin{array}{c}\delta_{\mathrm{s}}^{(p)} \\
(\mathrm{cm})\end{array}$ & $D_{f}$ & $\begin{array}{l}(5) \\
(\mathrm{cm})\end{array}$ & $D_{f}$ \\
\hline \multirow{3}{*}{ SS41 } & & 0.591 & 24.5 & & 5.68 & 0.518 & & 0.519 & \\
\hline & Type $\mathbf{A}$ & \begin{tabular}{|l|}
0.352 \\
0.445
\end{tabular} & $\begin{array}{r}59.0 \\
40.5\end{array}$ & 263.0 & 5.01 & $\begin{array}{l}0.290 \\
0.379\end{array}$ & 0.984 & $\frac{0.287}{0.377}$ & 0.985 \\
\hline & Type B & 0.250 & 119.0 & 319.2 & 4.67 & 0.193 & 1.014 & 0.190 & 1.010 \\
\hline \multirow[b]{2}{*}{ HT55 } & Type A & $\begin{array}{l}0.601 \\
0.351\end{array}$ & $\begin{array}{l}14.5 \\
47.0\end{array}$ & 278.6 & $\begin{array}{l}9.36 \\
8.63\end{array}$ & $\begin{array}{l}0.478 \\
0.245\end{array}$ & 1.077 & $\begin{array}{l}0.479 \\
0.241\end{array}$ & 1.074 \\
\hline & Type B & $\begin{array}{l}0.461 \\
0.260\end{array}$ & $\begin{array}{l}22.5 \\
55.0\end{array}$ & 260.2 & $\begin{array}{l}8.88 \\
8.06\end{array}$ & $\begin{array}{l}0.347 \\
0.160\end{array}$ & 0.887 & $\begin{array}{l}0.345 \\
0.156\end{array}$ & 0.886 \\
\hline \multirow[b]{2}{*}{ HT60 } & Type A & $\begin{array}{l}0.601 \\
0.350\end{array}$ & $\begin{array}{l}15.5 \\
50.0\end{array}$ & 299.2 & $\begin{array}{l}9.58 \\
8.53 \\
\end{array}$ & $\begin{array}{l}0.481 \\
0.246\end{array}$ & 1.085 & $\begin{array}{l}0.483 \\
0.242\end{array}$ & 1.083 \\
\hline & Type B & $\begin{array}{l}0.461 \\
0.261\end{array}$ & $\begin{array}{l}26.5 \\
73.0\end{array}$ & 278.3 & $\begin{array}{l}8.17 \\
7.38\end{array}$ & $\begin{array}{l}0.350 \\
0.162\end{array}$ & 1.047 & $\begin{array}{l}0.348 \\
0.159 \\
\end{array}$ & 1.044 \\
\hline
\end{tabular}

$D_{f}$ 值は $0.886 〜 1.074$ とほほ 1.0 に近く、「(8) 式で得られ る $D_{f}$ が 1.0 の時に疲労破壊が起こる』という PalmgrenMiner 型の線形累積損傷則がほぼ成立することがわかる。

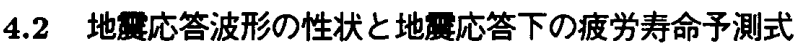

次に、(8) 式の多段多重疲労実験における PalmgrenMiner 則による累積損傷算定式を、地震応答下において も用いることができるように、拡張、一般化する。

Fig.11に、文献 2) で得られた 7 質点系 Standard model における第 3 層の履歴減衰装置のピン間相対変位時刻歴を、 エルセントロ NS波およびタフト $\mathrm{EW}$ 波の 2 つの地震波に ついて示す。これを見ると、波形は平均值 0 回りで振動し ており、漸增、漸減のループ (図中、点線)とそれ以外の 完全ループとから構成されていることがわかる。

Palmgren-Miner 則では、載荷の順序にかかわらず (8) 式が成立すると考えるから、今、 $\mathrm{k}$ 回目の半ループを繰り 返し載荷した時の $N_{f}$ の值を $N_{f, k}$ と表すことにすると、累 積損傷値： $D_{f}$ は、次式となる。

$$
D_{f}=\sum_{k}\left(\frac{1}{N_{f, k}}\right)
$$
ここに、

$\sum_{k}:$ 各半ループについての総和

(9) 式に (5) 式を代入、整理すると、

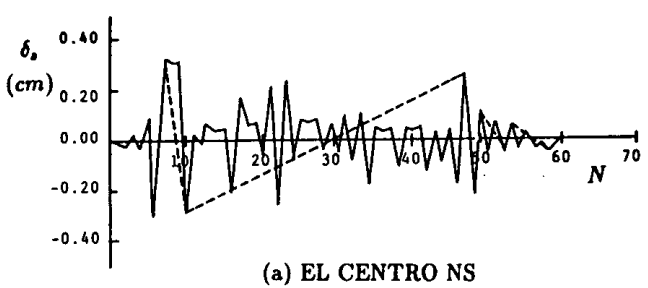

(a) EL CENTRO NS

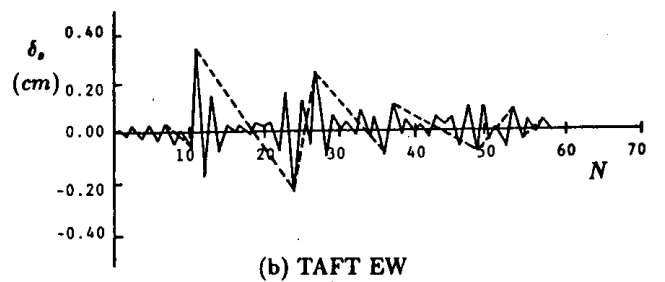

Fig. 11 Illustrations of displacement response to earthquake ground motion

$D_{f}=2 \cdot \sum_{k}\left|\frac{\delta_{s a, k}^{(p)}}{\delta_{s f}}\right|^{1 / c}$

ここに、

$\delta_{s a, k}^{(p)}: \mathrm{k}$ 回目の半ループ繰り返し載荷時の塑性 ピン間相対変位振幅

ところで、よく知られているように、(10) 式を用いて 各半ループについての損傷值を初期状態から順次計数して いくと、累積損傷值は過小評価される 7)。非定常振幅下に おける損傷を、より実状に即してサイクルカウントする代 表的な方法として、レンジペア計数法 7)とレインフロー法 11),12) とがある。前者は、『全履歴から完全なループを取 り出した後に、その残りを半サイクル毎に計数する』もの であり、後者は、その名の示すように、『初期から雨垂れ が落ちていく様を想起させるアルゴリズムで大ループを計 数し、それに含まれない小ループを順次計数する』もので ある。全履歴の振幅の最大值から前後にレンジペア法を用 いて計数すると、レインフロー法の計数結果と一致するこ とから、本研究では、初期状態から順次計数ができ、かつ 計数アルゴリズムの簡単なレインフロー法を採用すること とする。Fig.11には、レインフロー法で計数した大ループ を破線で示している。この計数方法を用いると、地震応答 下における疲労寿命予測式は、次式となる。

$$
D_{f}=1
$$

ここに、

$$
\begin{aligned}
& D_{f}=2 \cdot \sum_{k r}\left|\frac{\delta_{s a, k r}^{(p)}}{\delta_{s f}}\right|^{1 / c} \\
& \text { また、 } \\
& \sum_{k r}: \text { レインフロー法を用いて計数した場合の } \\
& \text { 各半ループの総和 }
\end{aligned}
$$


Table 6 Damage factors under cyclic loading with varying amplitude

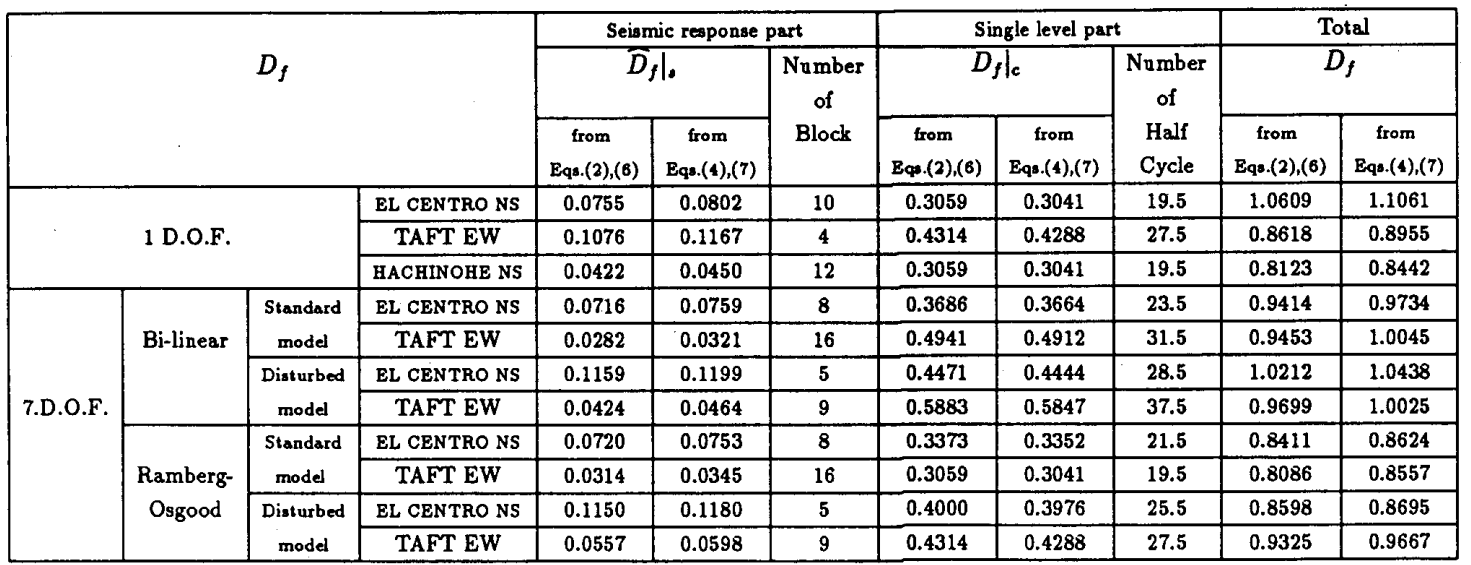

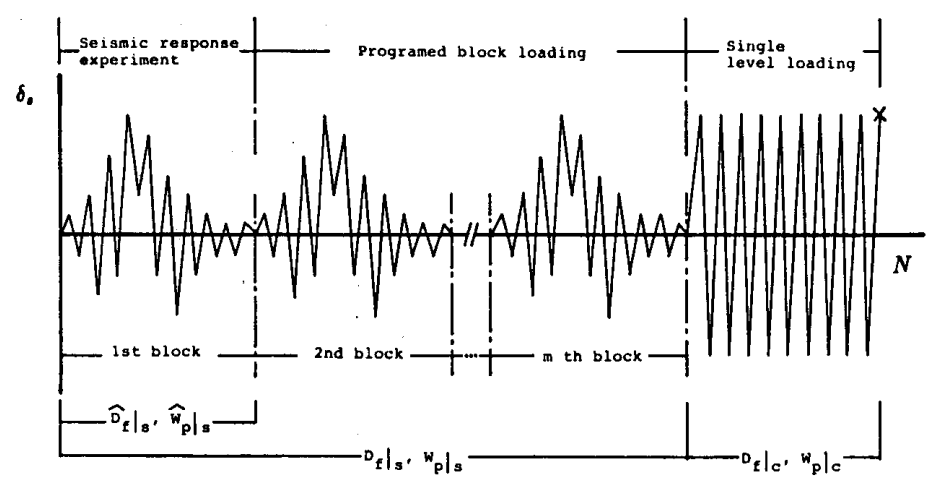

Fig. 12 Loading program adopted in cyclic loading test with varying amplitude

\section{3 線形累積損偒則の実地震応答下への適用性}

4.2 項で示した疲労寿命予測式の実地震応答下への適用 性を検証するために、HT60の試験体について、非定常振 幅疲労実験を行った。

文献 1)、2)に示した 1 質点系および 7 質点系の制振ブ レース付鉄骨架構の実地震応答実験から得られたピン間相 対変位時刻歴を、(11-b) 式で算定される累積損傷值： $D_{f}$ がほほ 0.5 となるように数ブロック載荷した後に、ピン間 相対変位振幅を $0.40(\mathrm{~cm})$ とした定振幅で繰り返し載荷し、 耐力が定振幅時の最大耐力の 9 割に低下するまでの繰り返 し回数： $N$ を求める、非定常振幅疲労実験を行った。採用 した載荷方法の概要を Fig.12に示す。

用いた実地震時ピン間相対変位時刻歴は、1 質点系に ついては、エルセントロNS波、タフトEW波、八戸N S 波についての応答の計 3 ケース、また、7質点系について は、適正な第 1 分岐強度分布を持つ構造モデル (Standard model) および第 3 層の強度を適正值から 2 割低減した構造 モデル (Disturbed model)の 2 つの振動モデルそれぞれに ついて、復元力特性を求めるための実験を行わない層の復 元力特性を Bi-linear 型および Ramberg-Osgood 型に近似 し、入力地震波を、エルセントロ NS波、タフトEW波と したものの、計 8 ケースについての第 3 層の応答である。
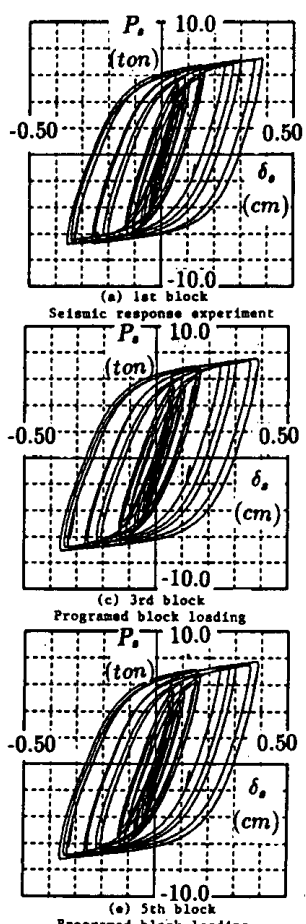

(o) Sth block
Progremed block load Ing (c) 3rd block
Programad block looding

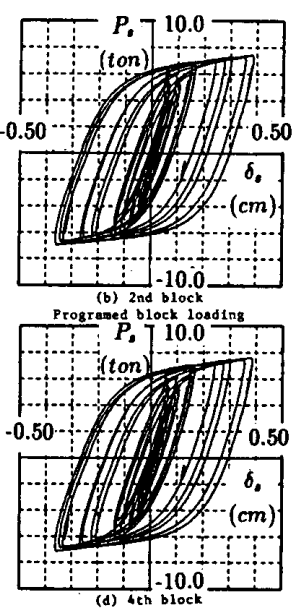

rogramed block loading

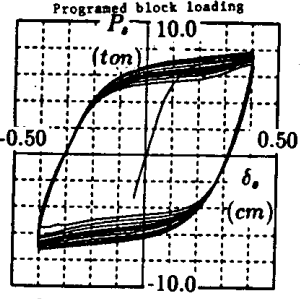

(f) Single level loading
Fig. $13 P_{s}-\delta_{s}$ relatious under cyclic loading with varying amplitude

実験を行わない層の復元力特性を Bi-linear 型とした、 7 質点系 Disturbed model の、エルセントロN S波に対する ピン間相対变位時刻歷を用いた非定常振幅疲労実験におけ る、荷重： $P_{s}$-ピン間相対変位： $\delta_{s}$ 関係を Fig.13に示す。 図中、(a) は実地震応答実験時の $P_{s}-\delta_{s}$ 関係であり、(b) (e) は、(a) で得られたピン間相対変位時刻歴に沿って強制 変位を与える実地震応答載荷実験時の $P_{s}-\delta_{s}$ 関係、また、 (f) は $0.4(\mathrm{~cm})$ の定振幅載荷実験時の $P_{s}-\delta_{s}$ 関係である。 この図から実地震応答実験時と実地震応答載荷時の $P_{s}-$ $\delta_{s}$ 関係は、ほとんど同じ履歴となることが分かる。

Table 6には、塑性ピン間相対変位振幅： $\delta_{s a}^{(p)}$ の算定式 を(2) 式及び (6) 式とした場合と (4) 式及び (7) 式とした 場合について、実地震応答実験時の累積損傷值 $:\left.\widehat{D}_{f}\right|_{s}$ 、実 
Table 7 Hysteretic absorbed energy under cyclic loading. with varying amplitude

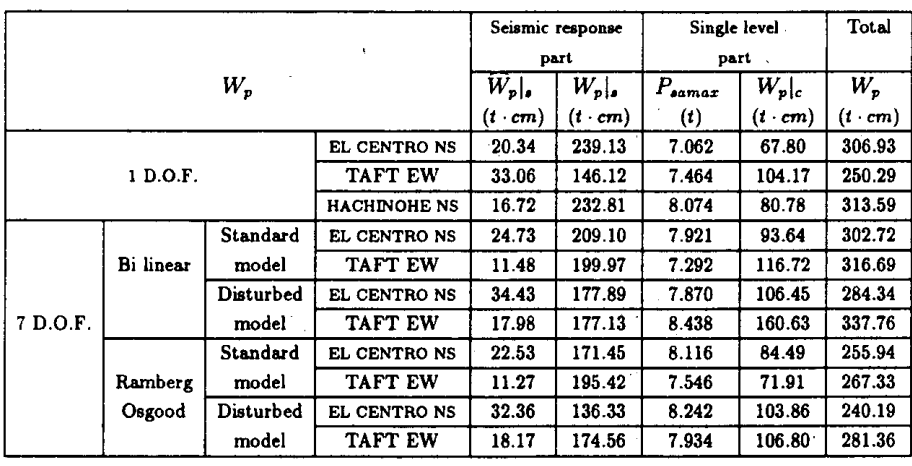

Table 8 Comparison of $D_{f}$ between experimental and analytical responses

\begin{tabular}{|c|c|c|c|c|c|}
\hline \multirow{2}{*}{\multicolumn{2}{|c|}{$D_{f}$}} & \multicolumn{2}{|c|}{ Stand ard model } & \multicolumn{2}{|c|}{ Distrurbed model } \\
\hline & & \multirow{2}{*}{$\begin{array}{c}\text { EL CENTRO } \\
\text { NS } \\
0.0632 \\
\end{array}$} & \multirow{2}{*}{$\begin{array}{c}\text { TAFT } \\
\text { EW } \\
0.0228\end{array}$} & \multirow{2}{*}{$\begin{array}{c}\text { EL CENTRO } \\
\text { NS } \\
0.1067\end{array}$} & \multirow{2}{*}{$\begin{array}{c}\text { TAFT } \\
\text { EW } \\
0.0489\end{array}$} \\
\hline \multirow{3}{*}{ Bi-linear } & Anal. & & & & \\
\hline & Exp. & 0.0716 & 0.0282 & 0.1159 & 0.0424 \\
\hline & $\frac{\lambda_{\text {nall }}}{B_{x p}}$ & 0.883 & 0.809 & 0.921 & 1.153 \\
\hline \multirow{3}{*}{$\begin{array}{c}\text { Ramberg- } \\
\text { Osgood }\end{array}$} & Anal. & 0.0746 & 0.0336 & 0.1162 & 0.0584 \\
\hline & Exp. & 0.0753 & 0.0345 & 0.1180 & 0.0598 \\
\hline & $\frac{\text { Ana. }}{E x p}$ & 0.991 & 0.974 & 0.985 & 0.977 \\
\hline
\end{tabular}

地震応答載荷実験時の載荷ブロック数： $n$ 、定振幅載荷実 験時の累積損傷值：D $\left.\right|_{f}$ および初期状態から破断に至るま での総累積損傷值：Dfを示している。

また、Table 7には、実地震応答実験時の履歴吸収エネル ギ一量: $\left.\widehat{W}_{p}\right|_{s}$ 、実地震応答実験時と実地震応答載荷実験時 のエネルギー吸収量の累計： $\left.W_{p}\right|_{s}$ 、定振幅載荷実験時の最 大耐力: $P_{\text {samax }}$ 、定振幅載荷時の履歴吸収エネルギー量： $\left.W_{p}\right|_{c}$ および総履歴吸収エネルギー量： $W_{p}$ を示している。

これらの表より、総履歴吸収エネルギー： $W_{p}$ は、各供試 体で多少ばらつくが、一方、総累積損傷値：Dにについて は、いずれのケースについても、ほほ1前後の值を示し、 特に、 $\delta_{s a}^{(p)}$ の算定式として、(4) 式、(7) 式を用いた場合に は、そのばらつきはより小さくなること等のことがわかる。 従って、塑性ピン間相対変位: $\delta_{s a}^{(p)}(4)$ 式、(7) 式により 評価し、累積損傷值： $D_{f}$ として (11-b) 式を用いれば、非 定常振幅疲労についても線形累積損傷則が十分適用可能で あることがわかる。

\section{5. 激・烈霹時における累積損傷值と応答塑性率 および累樻塑性変形応答倍率との相関関係}

前節では、オンライン・コンピュータ制御実地震応答実 験から得られた実地震ピン間相対変位時刻歴を用いた非定 常振幅疲労実験を行い、塑性ピン間相対変位を、(2) 式と (6) 式または (4) 式と (7) 式により算定し、累積損偒値を (11-b) 式とすれば、実地震応答下においても、線形累積損 傷則が十分適用可能であり、良好な精度で累積損傷值を評 価しうることを明らかにした。

本節では、4節に示した累積損傷值の算定式を用いて地 震応答解析より算定した累積損傷值と、オンライン・コン ピュータ制御実験より得られた累積損傷值とを比較するこ とにより、地震応答解析の有効性を確認すると共に、地動 最大速度： $V_{\max }$ を 20.0kine、40.0kine、60kine に基準化し た 3 種の地震波について、適正な構造特性を有する 3 層、 5 層、 7 層、9 層の各制振装置付ブレース架構の地震応答 解析を行い、激・烈震時の累積損傷値を明らかにする。ま た、文献 13)には、鉄骨架構柱フランジの累積損傷值は、
1 自由度フレーム構造物の地震応答解析から得られる履歴 吸収エネルギー量により、十分予測しうることが示されて おり、このことを参考に、通常よく用いられる応答塑性率 および累積塑性变形応答倍率と累積損傷值との間の相関関 係を調べ、これらの諸量により、各層の有孔鋼板の累積損 傷值: $D_{f, i}$ 值が予測可能かどうかについても検討する。

Table 8は、オンライン・コンピュータ制御実験と数值地 震応答解析との応答量の相違、特に累積損傷値の差異を見 るために、文献 1)、2) で行った実地震応答実験と地震応 答解析とから求めた $D_{f, i}$ 值を比較したものである。なお、 応答解析モデルは、4節に示したものと同様であり、ここ では 7 質点系についての結果のみを示している。

この表から、数值地震応答解析から求めた $D_{f, i}$ 值は、才 ンライン・コンピュータ制御実験より求めた值とほほ一致 しており、 $D_{f, i}$ 值は、数值応答解析により、実用上十分な 精度で把握できるものと考えられる。

なお、Ramberg-Osgood 型の数值復元力モデルと Bilinear 型数値復元力モデルの応答との間には、大きな差異 はないことなどから、以下に示す地震応答解析では、取り 扱いのより簡単な Bi-linear 型の数值復元力モデルを用い ることとし、また、塑性ピン間相対変位振幅： $\delta_{s a}^{(p)}$ は、(2) 式,(6) 式により求めている。

次に、Table 9に示す適正な構造特性 注 5) を有する $3 、 5 、$ 7、9 質点系の各構造モデルについて、エルセントロ N S 波、タフト EW波および八戸N S波の 3 種の地震波を用い た地震応答解析を行った代表的結果を、Fig.14及び Table 10に示す。

7 質点系の応答計算のうちで、最も累積損傷值の大きく なるエルセントロN S波を入力した場合について、地動最 大速度： $V_{\text {max }}$ を変化させた時のフレームの応答層間塑性 率: $\mu_{f, i}$ 、有孔鋼板の応答塑性率： $\mu_{s, i}$ 、最下層の応答せん 断力で無次元化した応答せん断力分布： $\beta_{\max , i}$ 、平均值で 無次元化した有孔鋼板の累積塑性変形応答倍率 : $\left(\eta_{s, i} / \bar{\eta}_{s}\right)$ および有孔鋼板の累積損傷值: $D_{f, i}$ の分布を、Fig.14に、ま た、Table 10には、フレームの応答層間塑性率 (平均值： $\bar{\mu}_{f}$ 、最大值： $\mu_{f \max }$ 、変動係数： $\left.v_{\mu f}\right)$ 有孔鋼板の応答塑性 
Table 9 Structural properties of sample buldings

\begin{tabular}{|c|c|c|c|c|}
\hline & 3 D.O.F. & 5 D.O.F. & 7 D.O.F. & 9 D.O.F. \\
\hline$T_{1}(\mathrm{sec})$ & 0.3855 & 0.5485 & 0.6970 & 0.9277 \\
\hline$B_{.}$ & 0.400 & 0.400 & 0.225 & 0.175 \\
\hline$n_{d}$ & 2 & 4 & 7 & 7 \\
\hline
\end{tabular}

$\alpha_{e, 1}=0.30, d_{y, n}=0.80, \gamma_{f, i}=0.30, \zeta_{f, i}=0.20$

$\zeta_{\Delta, i}=0.10, k_{b c, i}=1.00, n_{c}=24, h=0.02, \psi_{i}=45^{\circ}$

$H_{i}=370(\mathrm{~cm}), m_{i}=0.7480\left(t \cdot \mathrm{sec} / \mathrm{cm}^{2}\right)$

Table 10 Responses of 7 D.O.F. system to EL CENTRO NS earthquake as a function of maximum ground velocity

\begin{tabular}{|c|c|c|c|}
\hline & \multicolumn{3}{|c|}{$V_{\max }$} \\
\hline & 20 kine & 40 kine & 60 kine \\
\hline $\bar{\mu}_{f}$ & 0.4422 & 0.6853 & 0.9550 \\
\hline$\mu_{f_{\text {max }}}$ & 0.5376 & 0.8081 & 1.1006 \\
\hline$v_{\mu f}$ & 0.1617 & 0.1441 & 0.0999 \\
\hline$\ddot{\mu}_{.}$ & 2.0329 & 3.5053 & 5.1754 \\
\hline$\mu_{\text {amos }}$ & 2.4990 & 4.2453 & 6.2663 \\
\hline$v_{\mu}$ & 0.1740 & 0.1537 & 0.1537 \\
\hline$\tilde{\eta}_{0}$ & 8.293 & 30.987 & 58.911 \\
\hline$\eta_{e \max }$ & 11.474 & 40.887 & 74.629 \\
\hline$v_{\eta}$ & 0.1935 & 0.1841 & 0.1729 \\
\hline$\overline{D_{f}}$ & 0.0058 & 0.0429 & 0.1053 \\
\hline$D_{f_{\text {max }}}$ & 0.0118 & 0.0636 & 0.1411 \\
\hline$v_{D I}$ & 0.5299 & 0.2813 & 0.2309 \\
\hline
\end{tabular}
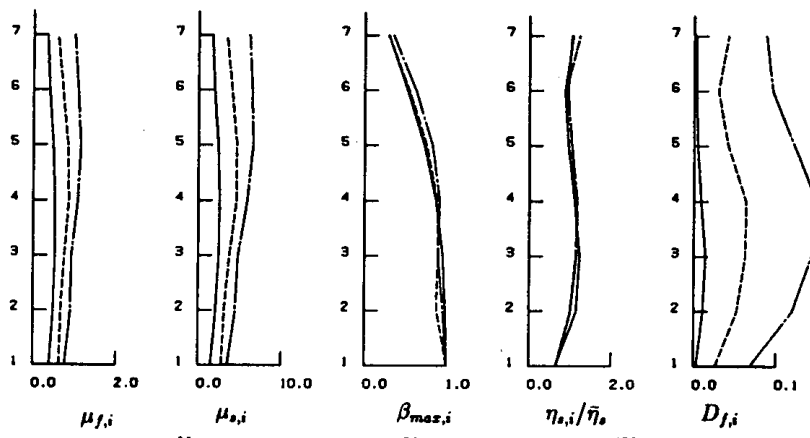

- $: V_{\text {mas }}=20(k$ ine $) \cdots \cdot-\cdots \cdot V_{\text {max }}=40($ kine $)---\cdot V_{\text {mes }}=60($ kine $)$

Fig. $14 \mu_{f, i}, \mu_{s, i},\left(\eta_{s, i} / \bar{\eta}_{s}\right)$, and $D_{f, i}$ distributions to EL CENTRO NS earthquake as a function of maximum ground velocity (7 D.O.F. system)

率 $\left(\right.$ 平均値 $: \bar{\mu}_{s}$ 、最大值： $\mu_{s m a x}$ 、変動係数: $v_{\mu s}$ )、有孔鋼 板の累積塑性変形応答倍率 (平均値 $: \bar{\eta}_{s}$ 、最大值 $: \eta_{s m a x}$ 、 変動係数: $v_{\eta s}$ )、有孔鋼板の累積損傷値 (平均值: $D_{f}$ 、最 大值： $D_{f \max }$ 、変動係数： $\left.v_{D f}\right)$ を示す注 6)。これ等 の結果より、 $\mu_{f, i} 、 \mu_{s, i}$ は、全層でほは一様となるが、 $\eta_{s, i}$ については、上層で若干の突出が見られること、地動最大 速度: $V_{\max }$ が $60.0 \mathrm{kine}$ の場合でも、 $D_{f, i}$ の值は 0.15 程度 に納まり、フレームに生じる塑性変形は、ほとんど無視し うる程度であること、また、有孔鎙板の損傷は、 $V_{\text {max }}$ を大 きくするにつれて增加し、その傾向は累積塑性変形伈答倍 率と似通っていること等のことがわかる。

次に、ここで行った地震応答解析より得られた、全ての 層の履歴減衰装置についての累積損傷值： $D_{f, i}$ と応答塑性 率： $\mu_{s, i}$ および累皘塑性変形応答倍率： $\eta_{s, i}$ との間の関係を、 3、5、7、9の各質点系にわけて、Fig.15、Fig.16に、それ
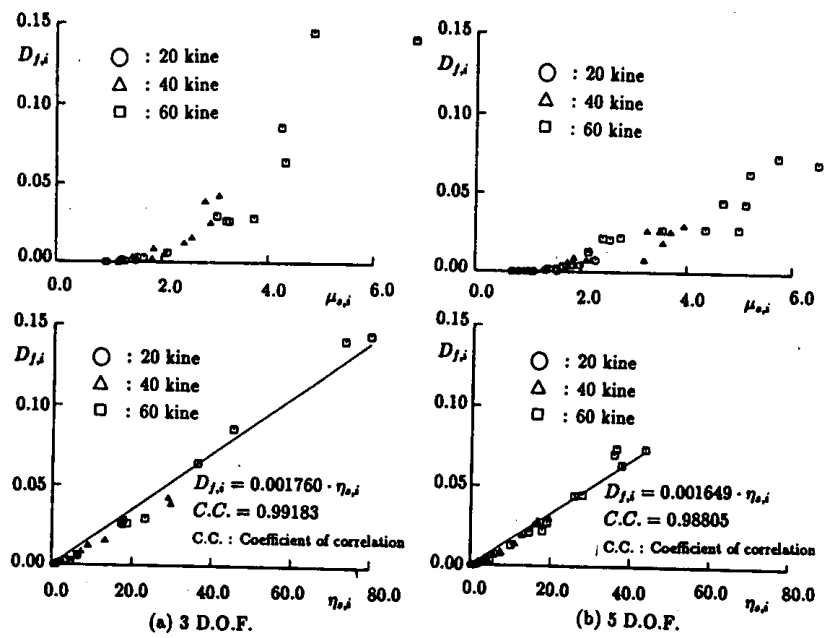

Fig. $15\left(D_{f, i}-\mu_{s, i}\right),\left(D_{f, i}-\eta_{s, i}\right)$ relationship of 3,5 D.O.F. system
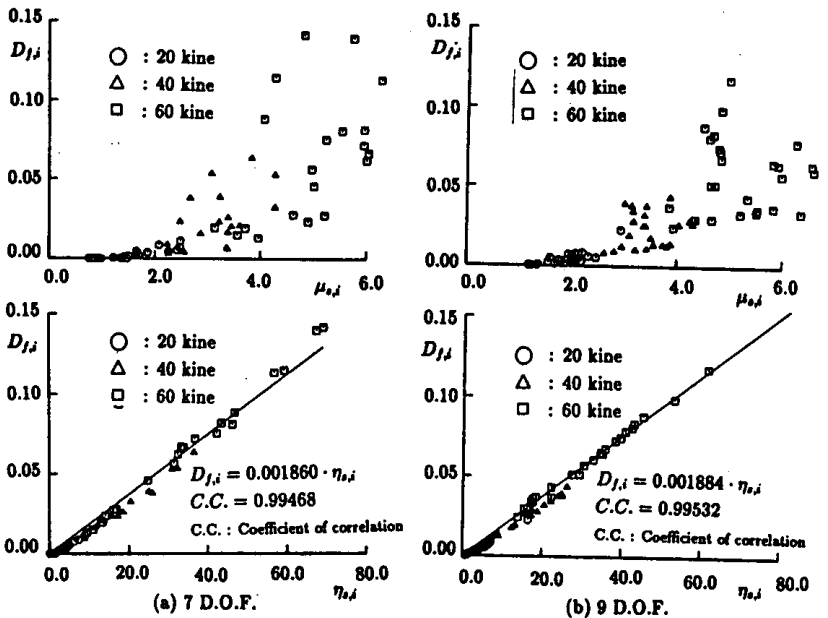

Fig. $16\left(D_{f, i}-\mu_{s, i}\right),\left(D_{f, i}-\eta_{s, i}\right)$ relationship of 7,9 D.O.F. system

ぞれ、示す。なお、図中の○、、、、は、それぞれ、地動 最大速度が、20.0kine、40.0kine、60.0kine のものであるこ とを表しており、また、同図中には、次式で表される、各 質点系ごとの $D_{f, i}$ と $\eta_{s, i}$ との最小 2 乗近似直線も併せて示 している。

$$
\begin{aligned}
& D_{f, i}=0.001760 \cdot \eta_{s, i} \quad \text { for } 3 \text { D.O.F.system } \quad \cdot \text { (12-a) } \\
& D_{f, i}=0.001649 \cdot \eta_{s, i} \quad \text { for } 5 \text { D.O.F.system * (12-b) } \\
& D_{f, i}=0.001860 \cdot \eta_{s, i} \quad \text { for } 7 \text { D.O.F.system } \cdots(12 \text {-c) } \\
& D_{f, i}=0.001884 \cdot \eta_{s, i} \quad \text { for } 9 \text { D.O.F.system } \cdots(12-\mathrm{d}) \\
& \text { この結果から、 } D_{f, i}-\mu_{s, i} \text { 関係の相関は小さく、大きく }
\end{aligned}
$$
ばらつくのに対し、 $D_{f, i}-\eta_{s, i}$ 関係は、地震波や地動最大 速度及び層数が異なってもほほ同一の直線上にのり、その 相関係数も $0.98805 \sim 0.99532$ と非常に高い相関関係を示 す值となっていることがわかる。 


\section{6. 結 び}

本報告では、著者等が提案している履歴減衰装置の極低 サイクル疲労特性を明らかにするため、各種の疲労実験を 行った。また、適正な構造特性を有する建物の実地震応答 解析を行い、激・烈震時にお舛る累皘損傷等について検討 した。得られた結論は、以下のように要約される。

1) 本履歴減衰装置は、十分な塑性変形能力を有し、大き な塑性変形を受けても急激な耐力低下は生じない。

2) 定振幅疲労特性として、Manson-Coffin 型の疲労関係 式が、 2 段 2 重載荷時には Palmgren-Miner の線形累 積損傷則が、よく成立する。

3）地震応答下においても、線形累積損傷則が成立すると 考えて差し支えなく、(2)式,(6) 式または (4) 式,(7) 式 および(11-b) 式を用いれば、実用上十分な精度で、累 積損慯值を算定することができる。

4) 累積損傷值と応答塑性率との間には、それ程強い相関 関係は見られないが、応答量の比較的小さな範囲につ いては、累積損傷値と累皘塑性变形応答倍率との間に は、ほほ線形関係が成立する。

5) 履歴減衰装置に生じる累積損傷值は、激震時（地動最 大速度で 60kine 程度）に扔いても 0.15 程度であり、本 履歴減衰装置は十分なエネルギー吸収能力を有する。

\section{謝辞}

本研究の経費の一部は、文部省科学研究補助金 (一般研究 B、研究代表者·花井正実 課題番号 01460195、奨励研究 A、研究代表者 玉井宏章 課題番号 01750585、02750476)、 牧田国際育英会第 2 回学術研究助成金 (研究代表者 花井 正実）で賄われました。また、元広島大学学生、西山正三 (現、大成建設)、中村英明 (現、フジ夕)、才門章彦（現、 鹿島建設)、倉本清哿 (現、鹿島建設)、竹中康博 (現、清 水建設)、谷口 栄 (現、竹中工務店) の諸兄には、実験 実施、資料整理に多大な協力を得ました。ここに記して、 謝意を表します。

\section{参考文献}

1）王井宏章、近藤一夫、花井正実：ブレース付架構制振装置の オンライン・コンピュータ制御地震応答実験、日本建築学会 構造系論文報告集、第 411 号、pp.107-116、1990 年 5 月.

2) 王井宏章、近藤一夫、花井正実:オンライン・コンピュー夕制 御によるブレース制振装置付中高層架構建築の実地震応答実 験、日本建築学会構造系論文報告集、第 423 号、pp.113-135、 1991 年 5 月.

3) 王井宏章、近藤一夫、花井正実:ブレース付架構の制振装置 に関する研究 その 1 履歴減衰装置の復元力特性、日本建 築学会構造系論文報告集、第 387 号、pp.24-34、1988 年 5 月.

4) 主井宏章、近藤一夫、花井正実: ブレース付架構の制振装置 に関する研究 その 2 楕円孔を有する有孔鋼板のエネル ギ一吸収性能について、日本建築学会構造系論文報告集、第 401 号、pp.139-149、1989 年 7 月.

5) 日本建築学会：地震荷重一その現状と将来の展望、丸善、 pp.170-221、1987 年.
6) P.C.Jennings : Earthquake Response of a Yielding Structure,Proc. of $A S C E$, Vol.90, No.EM4, pp.41-68, 1964.

7）日本材料学会編：金属疲労便覧、盖賢堂、pp.196-212、1978 年.

8) S.S.Manson : Thermal Stress and Low Cycle Fatigue, McGraw-Hill, pp.245-274, 1966.

9) M.A.Miner : Cumulative Damage in Fatigue, J. Appl. Mech., Trans.ASME, Vol.67, p.159, 1945.

10) G.Sachs,W.W.Gerberich,V.Weiss,J.V.Latorre : Low Cycle Fatigue of Pressure Vessel Materials, Proc. ASTM, Vol.60, pp.512-529, 1960 .

11）遠藤達雄、安在弘幸：簡明にされたレインフローアルゴリ ズム「P /V差法」について、材料、第 30 巻、第 328 号 pp.89-93、1981 年 1 月.

12）遠藤達雄、井上鏊：レインフロー法の考え方とその応用、日 本造船学会誌、第 706 号、pp.2-11、1988 年 4 月.

13) M.T.Suidan,R.A.Eubanks : Cumulative fatigue damage in seismic structures, Proc.ASCE , ST5, pp.923-943, 1973.

注

注 1）鋼材の材質によっては、荷重の繰り返しに伴う軟化や硬 化が生じるが、これらに起因する弾性变形成分の增減は、 塑性変形量全体からみれば小さい。

注 2) 定振幅載荷時の耐力は、例えば、Fig. 7から分かるよう に、最大耐力の 9 割程度となった付近で、載荷の繰り返 しとともに:急激に低下しはじめる傾向にあり、また、 地震時に、ある特定の層に強度の低下が生じると、その 層に損傷が集中する傾向にあるため2)、本研究では、こ うした点を考慮して、本履歴減衰装置の使用限界繰り返 し回数: $N_{f}$ として、耐力が最大耐力の 9 割に低下した時 点での繰り返し回数を探用している。

注 3) $\delta_{s f}$ 值は、定振幅疲労実験結果を $N_{f}=\frac{1}{2}$ まで外挿するこ とにより求めている。

注 4）（10) 式には、平均塑性変形量の影響が考慮されていない。 门平均塑性ひずみの影響として、単調載荷時の破断ひず みがその分だけ減少する」と考える Sachs-Weiss 則 10) の引数を、塑性ピン間相対変位に焼き直して考えると、 (10)式は、次式となる。

$$
D_{f}=2 \cdot \sum_{k}\left|\frac{\delta_{s a, k}^{(p)}}{\delta_{s f}-\delta_{s m, k}^{(p)}}\right|^{1 / c}
$$

ここに、

$\delta_{s m, k}^{(p)}: \mathrm{k}$ 回目の半ループ絽り返し載荷時の平均塑性 ピン間相対変位掁幅

なお、3節に示した単調引張実験結果によれば、履歴 減衰装置の破断ピン間相対変位： $\delta_{s f}$ は、Fig.11に示与平 均芣性ピン間相対変位量に比べ、十分大きいから、 $D_{f}$ 值 に対する $\delta_{s m}^{(p)}$ の影響は小さく、実用上は、(10) 式で十分 であると思われる。

注 5) 種々の実地震応答計算結果より適正構造特性值を算定し ている。各構造特性パラメータの詳細については、文献 2)を参照されたい。

注 6) フレームの応答層間塑性率： $\mu_{f, i}$ および有孔鋼板の応答 塑性率： $\mu_{s, i}$ は、各層の最大層間変位および最大ピン間 变位をそれそれの弾性限変位で除したものとして、また、 有孔鋼板の累積塑性変形芯答倍率: $\eta_{s, i}$ は、有孔鋼板が経 験した塑性変形量の累積和を有孔鋼板の弾性限変位で無 次元化したものとして定義している。また、変動係数と は標準偏差を平均值で除したものであり、分布の変動を 相対的に比較するために用いる。

(1993 年 12 月 9 日原稿受理, 1994 年 5 月 31 日採用決定) 